\title{
After the Massacre: Women's Islamist activism in Post-Coup Egypt
}

Sarah ElMasry and Neil Ketchley ${ }^{1}$

\begin{abstract}
This paper draws on event data and interviews to examine the effects of repression on the gendered dynamics of Islamist mobilization in Egypt following the 2013 military coup. Our analysis shows that women's anti-coup groups were more likely to mobilize following the killing of up to 1,000 anti-coup protestors at Rabaa al-Adawiyya in August 2013. Women's protests were also more likely in the home districts of those killed at Rabaa. Informant testimony indicates that the Rabaa massacre figured as a transformative event that female activists drew on to motivate their involvement in street protests. Taken together, our findings suggest that very harsh repression can enable women's participation in Islamist street politics --- but this activism can come at a considerable personal cost for participants. Women who joined anti-coup protests were subjected to calibrated sexual violence by Egyptian security forces, as well as other social penalties.
\end{abstract}

\section{Keywords}

Egypt; Rabaa massacre; Muslim Brotherhood; Muslim Sisters; Repression; Mobilization

\section{Introduction}

\footnotetext{
${ }^{1}$ Authors are listed in alphabetical order; both contributed equally. An early version of this paper was presented at the 2017 Annual Conference of the American Political Science Association and at a workshop on "Islamists in Hard Times" organized by the Project on Middle East Political Science. We are grateful to Mark Beissinger, Jillian Schwedler, Marc Lynch, and two anonymous reviewers, for comments and feedback. Sarah ElMasry is a Ph.D. Candidate in Political Science and Sociology at the Scuola Normale Superiore. Neil Ketchley is Associate Professor of Political Science at the University of Oslo. Direct correspondence to sarah.elmasry@sns.it and neil.ketchley@stv.uio.no.
} 
"Before the coup, there was no mixing between men and women in the Muslim Brothers. Now there is a coup. We [men and women] have to sit together to fight the coup. Rules are being broken and there is a transformation" (Abdullah, interview 24 Feb. 2014).

Scholars of political Islam increasingly highlight the important, albeit often occluded, roles played by women in launching and sustaining Islamist activism. Such studies suggest that women are frequently key actors in the informal networks and back office politics that underpin male-dominated Islamist movements and political parties. ${ }^{2}$ This literature forms part of a broader vein of scholarship that charts how Muslim women exercise agency in ways that defy simplistic tropes rooted in their supposed quiescence and passivity. ${ }^{3}$ A related body of research on the 2011

\footnotetext{
${ }^{2}$ See especially Janine Clark, "Islamist Women in Yemen: Informal Nodes of Activism" in Islamic activism: a social movement theory approach, ed. Quintan Wiktorowicz (Bloomington: Indiana
} University Press: 2003), 164-184; Janine Clark and Jillian Schwedler, "Who Opened the Window? Women's Activism in Islamist Parties," Comparative Politics 35:3 (2003): 293-312 ; Meriem Haitami, "Islamist Feminism in Morocco: (Re)defining the Political Sphere," Frontiers 37:3 (2016): 7; Katarína krabáková, "Islamist Women as Candidates in Elections: A Comparison of the Party of Justice and Development in Morocco and the Muslim Brotherhood in Egypt," Die Welt des Islams 57:3-4 (2017): 329-359.

${ }^{3}$ Swati Parashar, “The Sacred and the Sacrilegious: Exploring Women's 'Politics' and 'Agency' in Radical Religious Movements in South Asia," Totalitarian Movements and Political Religions 11 (2010): 435-455; Rochelle Terman, "The Piety of Public Participation: The Revolutionary Muslim Woman in the Islamic Republic of Iran," Totalitarian Movements and Political Religions 11 (2010): 289-310; Sherine Hafez, An Islam of her own: Reconsidering religion and secularism in women's Islamic movements (New York: New York University Press, 2011); Sherine Hafez, Women of the Midan: the untold stories of Egypt's revolutionaries (Bloomington: Indiana University Press, 2019); Mariz Tadros, "Does revolutionary politics reconfigure Islamist women's agency organizationally? The case of the Muslim Sisters of the Muslim Brotherhood in Egypt (1928-2013)," Feminist Dissent (2017): 85-114; Erika Biagini, "Islamist women's feminist subjectivities in (r)evolution: the Egyptian Muslim Sisterhood in the aftermath of the Arab uprisings," International Feminist Journal of Politics (2019): 1-21. 
Arab Spring underlines the crucial role that women play in regional episodes of mass protest. ${ }^{4}$ This paper contributes to all three literatures by considering mobilization by women-led Islamist movements in post-coup Egypt, at a time when the new military-backed government was launching massive repression against supporters of ousted president Muhammad Mursi. While previous studies have sought to explain female participation in Islamist groups in a variety of contexts, this activism has almost always occurred at a distance from frontline, street-level protest. Against this backdrop, the emergence of women-led protest groups in Egypt --- who staged daily marches, demonstrations and sit-ins in opposition to the 2013 coup --- points to a quite different trajectory to those more studied forms of activism.

In seeking to explain the rise of women's anti-coup movements in Egypt, this paper examines the role of repression in shaping the incidence of women's protest. ${ }^{5}$ In particular, we explore two inter-related explanations that might account for the timing and spaces of this activism, derived from the wider case literature on the gendered dynamics of activism in patriarchal and repressive contexts. The first explanation keys the emergence of women's protests to the local availability of male activists. According to this argument, male-dominated movements turn to female members to coordinate and stage protests in a bid to maintain a street presence following the mass arrest of male members. An alternative explanation sees harsh repression as a grievance that women draw on to justify their participation in street-level mobilization. In this mode, harsh repression figures as a transformative event that women can leverage to challenge their exclusion from frontline protest activities.

\footnotetext{
${ }^{4}$ Nermin Allam, Women and the Egyptian revolution: engagement and activism during the 2011 Arab uprisings (New York: Cambridge University Press, 2018); Hafez, Women of the Midan: the untold stories of Egypt's revolutionaries.

${ }^{5}$ We follow Earl (2011) in understanding repression as "state or private action meant to prevent, control, or constrain noninstitutional, collective action (e.g., protest), including its initiation.” Jennifer Earl, "Political Repression: Iron Firsts, Velvet Gloves, and Diffuse Control," Annual Review of Sociology 37 (2011): 263.
} 
To conduct our analysis, we analyze event data derived from an Arabic-language newspaper published by the Muslim Brotherhood. Our statistical results show that the arrest of more Islamist males in a governorate does not predict subsequent mobilization by women's groups in the same area. This suggests that the mobilization of women's anti-coup groups is not simply reducible to women making up for a local shortfall of male protestors. Instead, women's anti-coup movements mobilized in increasing frequency following the massacre of up to 1,000 anti-coup protestors on 14 August 2013. Women were also more likely to mobilize in the home districts of anti-coup protestors killed at Rabaa. Along with interview testimony, these results suggest that the Rabaa massacre figured as a transformative event that patterned both the timing and spaces of women's participation in anti-coup protest. However, this came at a considerable personal cost for participants: women who joined anti-coup protests were subjected to calibrated sexual violence by Egyptian security forces, as well as other social penalties.

Theoretically, the paper contributes to the literature on the effects of repression on protest. Scholarship that takes either protest size or frequency as the dependent variable is notoriously indeterminate, with evidence for positive, negative, and non-monotonic associations. ${ }^{6}$ This has led repression researchers to ask different questions, focusing on the characteristics of a protest event that makes it more vulnerable to repression, ${ }^{7}$ and how

\footnotetext{
${ }^{6}$ Ronald Francisco, "After the Massacre: Mobilization in the Wake of Harsh Repression," Mobilization 9:2 (2004):107-126; David Hess and Brian Martin, "Repression, Backfire, and the Theory of the Transformative Event," Mobilization 11:2 (2006): 249-267; Susan Olzak, Maya Beasley, and Johan Olivier, "The Impact of State Reforms on Protest Against Apartheid in South Africa," Mobilization 8:1 (2003): 27-50; Karl-Dieter Opp and Wolfgang Roehl, "Repression, Micromobilization, and Political Protest," Social Forces 69:2 (1990): 521-547; Karen Rasler, "Concessions, Repression, and Political Protest in the Iranian Revolution," American Sociological Review 61:1 (1996): 132-152.

${ }^{7}$ Paul Chang and Alex Vitale, "Repressive Coverage in an Authoritarian Context: Threat, Weakness, and Legitimacy in South Korea's Democracy Movement," Mobilization 18:1 (2013): 19-39; Jennifer Earl and Sarah Soule, "Seeing Blue: A Police-Centered Explanation of Protest Policing," Mobilization
} 
repression affects other qualities of contentious politics. ${ }^{8}$ This chapter takes up the second line of inquiry, by examining the effects of repression on gender relations within a highly patriarchal Islamist movement. In doing so, it aims to illuminate how repression can function as both an opportunity and a cost for women marginalized from street protest.

The paper is structured as follows: it begins by considering the case literature on the gendered dynamics of contentious collective action in contexts of repression. It then outlines the case of women's participation in Islamist activism in Egypt following the 2013 military coup. After describing our data and method, we present the quantitative results. A discussion then considers qualitative information from interviews with a view to expanding on the statistical findings. We conclude by reflecting on the gendered costs of participation in anti-coup activism in Egypt.

\section{Gender, Repression and Mobilization}

A significant body of research seeks to understand the dynamics of women's collective protest under conditions of patriarchy. ${ }^{9}$ That literature suggests that gender roles can be transformed

11:2 (2006):145-164; Jennifer Suzanne Earl, Sarah A. Soule, John D. McCarthy, "Protest under Fire? Explaining the Policing of Protest," American Sociological Review 68:4 (2003): 581-606.

${ }^{8}$ Paul Chang, "Unintended Consequences of Repression: Alliance Formation in South Korea's Democracy Movement (1970-1979)," Social Forces 87:2 (2008) :651-677; Neil Ketchley, Egypt in a Time of Revolution: Contentious Politics and the Arab Spring (Cambridge: Cambridge University Press; 2017); Dana Moss, "Repression, Response, and Contained Escalation Under "Liberalized" Authoritarianism in Jordan," Mobilization 19:3 (2014): 261-286.

${ }^{9}$ Linda Lobao, "Women in Revolutionary Movements: Changing Patterns of Latin American Guerrilla Struggle," Women and Revolution: Global Expressions (1990): 255-290; Wunyabari Maloba, African women in revolution (Trenton: Africa World Press, 2007); Valentine Moghadam, "Gender and revolutions," in Theorizing Revolutions ed. John Faron (London: Routledge, 1997); Belinda Robnett, “African-American Women in the Civil Rights Movement, 1954-1965: Gender, Leadership, and Micromobilization," American Journal of Sociology 101:6 (1996): 1661-1693; Belinda Robnett, How long? How long? African-American women in the struggle for civil rights 
during episodes of mass mobilization, leading to new opportunities for women to participate in the public sphere. ${ }^{10}$ Here, the ways in which women engage in contentious collective action are myriad: from providing medical care and supplying food, to participating in street demonstrations and assuming leadership position. ${ }^{11}$ In this section, we draw on this literature to isolate two ways in which repression can enable women's participation in Islamist activism. We begin by considering how repression can create opportunities for women's frontline protest activities by affecting the organizational capacity of male-led social movements. We then explore how repression can feature as a transformative event in the life cycle of a mobilization, which women draw on to justify their participation in contentious action. Subsequent sections relate these dynamics to the trajectory of women's involvement in the anti-coup movement in Egypt.

\subsection{Organizational capacity}

The impact of repression on social movements' ability to mobilize is well-documented. As Sullivan (2016) chronicles, state repression raises the costs of carrying out routine movement activities, including holding meetings and training workshops. This, in turn, "undermines the capacity of organizations to coordinate collective action." 12 Moreover, the arrest and killing of members of a social movement can significantly curtail a movement's ability to sustain lines of

(New York: Oxford University Press, 1997); Jocelyn Viterna, Women in war the micro-processes of mobilization in El Salvador (New York: Oxford University Press, 2013); Georgina Waylen, Engendering transitions: women's mobilization, institutions, and gender outcomes (Oxford: Oxford University Press, 2007).

${ }^{10}$ Robnett, How long? How long? African-American women in the struggle for civil rights; Lisa Baldez, Why women protest: women's movements in Chile (Cambridge: Cambridge University Press, 2002), 11.

${ }^{11}$ Moghadam, "Gender and revolutions."

${ }^{12}$ Christopher Sullivan, "Political Repression and the Destruction of Dissident Organizations," World Politics 68:4 (2016): 647. 
communication and maintain a frontline protest presence. ${ }^{13}$ According to several studies, such organizational considerations are often a key element in explaining variation in the timing of women's mobilization. Viewed in this mode, repression functions as a potential opportunity for women to mobilize, by equalizing gender relationships within a social movement struggling to fulfil basic functions. ${ }^{14}$ The dynamic underpinning this relationship is intuitive. As Lobao notes, repression affects the resources available for social movement organizations and so a "shortage in personnel may also open opportunities to play new roles," which are often filled by women. ${ }^{15}$

In her study of the U.S. civil rights movement, Robnett $(1996 ; 1997)$ found that women acted as "bridge leaders" - connecting the male-led movement to local constituencies. Here, women were largely excluded from formal leadership positions in the male-led civil rights movement, even though they sometimes took on local roles in coordinating informal organizing. ${ }^{16}$ However, during periods of crisis brought on by repression, when large numbers of male civil rights leaders were arrested, women took on more prominent leadership roles. We see a similar dynamic in authoritarian contexts, when regimes crack down on male-led opposition groups. In Tunisia, for example, male members of the Islamist Ennahda movement were imprisoned and tortured by the Ben Ali regime. ${ }^{17}$ During these periods of prolonged repression, female Ennahda members took on key organizational roles, such as passing on messages and keeping open channels of communication within the movement, in turn becoming "self-

\footnotetext{
${ }^{13}$ Francisco, "After the Massacre: Mobilization in the Wake of Harsh Repression."

${ }^{14}$ Christian Davenport, Hank Johnston, and Carol Mueller, Repression and mobilization (Minneapolis: University of Minnesota Press, 2005); Earl, "Political Repression: Iron Firsts, Velvet Gloves, and Diffuse Control."

${ }^{15}$ Lobao, "Women in Revolutionary Movements: Changing Patterns of Latin American Guerrilla Struggle," 217.

${ }^{16}$ Robnett, How long? How long? African-American women in the struggle for civil rights (New York: Oxford University Press, 1997), 20-24.

${ }^{17}$ Anne Wolf, Political Islam in Tunisia: the history of Ennahda (London: Hurst Publishers, 2017).
} 
supporting and independent" activists in their own right. ${ }^{18}$ Indeed, the movement's ability to regroup in the post-Ben Ali period after a prolonged exile is, in part, attributable to the role played by female members in sustaining local networks and party structures. ${ }^{19}$ These dynamics are suggestive of 'gendered opportunity structures' in contexts where "opportunities and constraints are different for men than for women." ${ }^{20}$ In this conception, state targeting of maledominated movements can dramatically alter the gender balance both within a movement and across the broader political field, as the necessity of maintaining collective action ensures that the exclusion of women from streel-level activities can no longer be justified.

\subsection{Repression as grievance}

A second body of literature points to the role of grievances in patterning women's participation in protest. ${ }^{21}$ In such accounts, women's movements crystallize around shared experiences of state repression, often following the death or detention of relatives. In Argentina, the Madres of the

\footnotetext{
${ }^{18}$ Ibid., 86; Doris Gray, “Tunisia after the Uprising: Islamist and Secular Quests for Women's Rights," Mediterranean Politics 17:3 (2012): 285-302; Doris Gray, and Terry Coonan, "Notes from the Field: Silence Kills! Women and the Transitional Justice Process in Post-Revolutionary Tunisia," International Journal of Transitional Justice 7:2 (2013): 348-357.
}

${ }^{19}$ Gray and Coonan, "Notes from the Field: Silence Kills! Women and the Transitional Justice Process in Post-Revolutionary Tunisia"; Loes Debuysere, "Tunisian Women at the Crossroads: Antagonism and Agonism between Secular and Islamist Women's Rights Movements in Tunisia," Mediterranean Politics 21:2 (2016): 226-245; Wolf, Political Islam in Tunisia: the history of Ennahda.

${ }^{20}$ Rachel Kutz-Flamenbaum, "Mobilizing Gender to Promote Peace: The Case of Machsom Watch," Qualitative Sociology 35:3 (2012): 294.

${ }^{21}$ Victor Asal, Richard Legault, Ora Szekely, and Jonathan Wilkenfeld, "Gender ideologies and forms of contentious mobilization in the Middle East." Journal of Peace Research 50:3 (2013): 305-318; Erica Chenoweth, Jay Ulfelder, "Can Structural Conditions Explain the Onset of Nonviolent Uprisings?” Journal of Conflict Resolution 61:2 (2016): 298-324; Erica Simmons, “Grievances do matter in mobilization," Theory and Society 43:5 (2014): 513-546. 
Plaza de Mayo famously drew on notions of motherhood to frame their mobilization, agitating for information about the whereabouts of their children while employing innovative protest tactics. $^{22}$ We find a not dissimilar dynamic in El Salvador, where the CoMadres, initially formed of mothers and relatives of political figures killed or disappeared by the right-wing government, crystallized into a cross-class alliance that occupied government offices and staged public protests. ${ }^{23}$ To sustain women's protest, CoMadres also engaged in other forms of associational activity, including providing health clinics, sewing workshops, and day-care centres. ${ }^{24}$

State violence, this literature suggests, can also be generative of women's activism. In Pinochet's Chile, women were arrested, raped, and tortured. ${ }^{25}$ These horrific abuses motivated the formation of women-only movements, who organized in opposition to several governmentcontrolled women's organizations run by Pincohet's wife. ${ }^{26}$ In El Salvador, brutal repression by the Salvadoran army --- including shelling civilian houses, extra-judicial killings of family members, and sexual violence --- provided powerful grievances for women to join the Faradundo Marti National Liberation Front. ${ }^{27}$ Female bridge leaders in the Salvadoran resistance movement were able to connect activists with previously unmobilized constituencies, in turn attracting

\footnotetext{
${ }^{22}$ Waylen, Engendering transitions: women's mobilization, institutions, and gender outcomes, 56.

${ }^{23}$ Waylen, Engendering transitions: women's mobilization, institutions, and gender outcomes; Jennifer Schirmer, "The Seeking of Truth and The Gendering of Consciousness: The CoMadres of El Salvador and the CONAVIGUA Widoes of Guatemala," in "Viva": Women and Popular Protest in Latin America, ed. Sarah A. Radcliffe, Sallie Westwood (London: Routledge), 44.

${ }^{24}$ Schirmer, "The Seeking of Truth and The Gendering of Consciousness: The CoMadres of El Salvador and the CONAVIGUA Widows of Guatemala," 46.

${ }^{25}$ Waylen, Engendering transitions: women's mobilization, institutions, and gender outcomes, 55.

${ }^{26}$ Baldez, Why women protest: women's movements in Chile (Cambridge: Cambridge University Press, 2002).

${ }^{27}$ Ilja Luciak, After the revolution: gender and democracy in El Salvador, Nicaragua, and Guatemala (Baltimore: Johns Hopkins University Press, 2001); Julia Denise Shayne, “Gendered Revolutionary Bridges," Latin American Perspectives 26:3 (1999): 85-102.
} 
supporters who went on to create a series of women-focused organizations. ${ }^{28}$ In Algeria, women defied gender boundaries to take leading roles in the resistance to French rule. This, despite women being initially assigned the role of "preserving the nation and the family" in the narrative of Algeria's national liberation movement. ${ }^{29}$ Key to breaking this mould was the severity and pervasiveness of repression by the French colonial authorities. ${ }^{30}$ Faced with daily injustices, Algerian women engaged in a struggle on two fronts: at once, fighting within the national liberation movement to take on combat and leadership position, and at the same time resisting the French occupation.

Taken together, these accounts suggest that experiences of repression can figure as "transformative events," which women draw on to justify their participation in contentious collective action. ${ }^{31}$ We now explore these dynamics as they relate to women's participation in the Egyptian anti-coup movement. In doing so, we expand on the case literature by considering the position of Islamist women mobilizing in the contemporary Middle East and North Africa.

\section{Women's Anti-Coup Activism in Egypt}

On 3 July 2013, the Egyptian military seized upon large street protests to stage a coup. In response, Islamist supporters of ousted president Muhammad Mursi launched daily street protests. The epicenter of the anti-coup mobilization was in Midan Rabaa al-Adawiyya, a public square in eastern Cairo, where members of the Muslim Brotherhood and other Islamist movements staged a well-resourced protest occupation calling for Mursi's reinstatement. Similar anti-coup occupations were established in over a dozen governorates across Egypt under the

\footnotetext{
${ }^{28}$ Ibid..

${ }^{29}$ Maloba, African women in revolution, 19.

${ }^{30}$ Ibid..

${ }^{31}$ Hess and Martin, "Repression, Backfire, and the Theory of the Transformative Event."
} 
umbrella of the "National Alliance to Support Legitimacy" - a protest organization led by the Muslim Brotherhood and comprising 14 other Islamist groups. ${ }^{32}$

[Figure 1 about here]

In a bid to demobilize opposition to the coup and consolidate its rule, the new militaryled government launched a massive crackdown against the Brotherhood and its allies. ${ }^{33}$ This saw a wave of arrests, as well as the use of live ammunition against anti-coup protestors. Figure 1 shows the arrest rate for male Islamists in the six months following the coup. State repression peaked on 14 August 2013, when police and military forces violently cleared the Rabaa occupation, in what Human Rights Watch (2014) have described as "the most serious incident of mass unlawful killings in modern Egyptian history." 34 To give a sense of the scale of this violence: the WikiThawra (2013) dataset, compiled by the Egyptian Centre for Economic and Social Rights, contains detailed biographical records for over 1,000 protestors killed at Rabaa. ${ }^{35}$ On the same day, security forces used similarly harsh violence to clear protest occupations located in other governorates. Denied a base of operations, the anti-coup movement continued to

\footnotetext{
${ }^{32}$ Neil Ketchley, "The Muslim Brothers Take to the Streets," Middle East Report 269 (2013): 12-17; Ketchley, Egypt in a Time of Revolution: Contentious Politics and the Arab Spring, Chap. 6.

${ }^{33}$ For more general accounts of how repression impacted anti-coup protest, see Khalil Al-Anani, "Rethinking the repression-dissent nexus: assessing Egypt's Muslim Brotherhood's response to repression since the coup of 2013," Democratization 26 (2019): 1329-1341; Jannis Grimm and Cilja Harders, "Unpacking the effects of repression: the evolution of Islamist repertoires of contention in Egypt after the fall of President Morsi," Social Movement Studies 17:1 (2018): 1-18; Ketchley, Egypt in a Time of Revolution: Contentious Politics and the Arab Spring, Chap. 6.

${ }^{34}$ Human Rights Watch, “All According to Plan: The Rab'a Massacre and Mass Killings of Protesters in Egypt," (2014) Available at: https://www.hrw.org/report/2014/08/12/all-according-plan/rabamassacre-and-mass-killings-protesters-egypt [Accessed 6 Feb. 2020].

${ }^{35}$ WikiThawra, (2013) Available at: https://docs.google.com/spreadsheets/d/1JO7jWfvuFLiV_A4ZmKDK0F1ZUKHtcUyIgc77J7Z6O4/edit\#gid=0 [Accessed 8 Jan. 2020].
} 
launch daily protests --- but were forced to mobilize in residential areas, and other spaces where the state lacked coercive capacity.

Against this backdrop, the emergence of women's anti-coup movements marked a radical departure in the gendered dynamics of Islamist mobilization in Egypt. A women's branch of the Muslim Brotherhood has existed in some form since the interwar period, and was originally conceived as a platform for providing women with religious guidance on their duties and responsibilities as wives and mothers. ${ }^{36}$ In the period following the Second World War, there were around 50 women's branches across Egypt. ${ }^{37}$ When the Brotherhood was dissolved by Nasser, the women's wing of the movement initially escaped state repression. Left free to operate, female members quickly came to act as a support network: they relayed messages between imprisoned male members of the movement and provided other forms of solidarity. ${ }^{38}$ Still, women remained largely excluded from both the organization's decision-making structures and street-level activism. Justifying this diminished role, Zainab al-Ghazzali, one of the leading female members of the movement during its early period, insisted that women's primary role was as "nurturers of the nation's men." 39

Instead, the Muslim Sisters, as they became known, were primarily involved in social service provision. The scope of their activities did begin to expand in the 1970s, when Sisters

\footnotetext{
${ }^{36}$ Omayma Abdellatif and Marina Ottaway, "Women in Islamist movements toward an Islamist model of women's activism," Carnegie endowment for international peace (2007) Available at: http://carnegieendowment.org/files/cmec2 women in islam final1.pdf [Accessed 6 Feb. 2020]; Mariz Tadros, The Muslim Brotherhood in Contemporary Egypt: Democracy redefined or confined? (London: Routledge, 2012); Ghada Talhami, The mobilization of Muslim women in Egypt (Gainesville: University Press of Florida, 1996).

${ }^{37}$ Talhami, The mobilization of Muslim women in Egypt, 48.

${ }^{38}$ Tadros, The Muslim Brotherhood in Contemporary Egypt: Democracy redefined or confined?, 122.

${ }^{39}$ Talhami, The mobilization of Muslim women in Egypt, 52.
} 
stood in student union elections and professional syndicates. ${ }^{40}$ In the years leading up to the 25 th January Revolution in 2011, Muslim Sisters also ran in municipal and parliamentary elections, and launched campaigns to raise awareness for detained male members detained by the Mubarak regime. ${ }^{41}$ During this later period, there is evidence that women actively lobbied inside the Brotherhood for a more prominent role - demanding better representation within the Brotherhood's decision-making structures and the full integration of the Sisters into the movement. ${ }^{42}$ These efforts were, however, stymied by the Brotherhood's male leadership, who insisted that any greater role for women risked exposing female members to repression by the Mubarak regime. This state of affairs largely continued after Egypt's democratic breakthrough in 2011, with the Brotherhood continuing to bar women from leadership positions. ${ }^{43}$

[Figure 2 about here]

The visibility and prominence of female members of the Muslim Brotherhood was to expand dramatically following the military's seizure of power and the rise of women's anti-coup protest movements. ${ }^{44}$ Figure 2 plots weekly protest events launched by women's groups in the

\footnotetext{
${ }^{40}$ Azza Karam, Women, Islamism, and the State: Contemporary feminisms in Egypt, (New York: Martin's Press, 1998).

${ }^{41}$ Omayma Abdel-Latif, "In the shadow of the brothers: the women of the Egyptian Muslim Brotherhood," Carnegie Endowment for International Peace (2008) Available at: http://carnegieendowment.org/files/women_egypt_muslim_brotherhood.pdf [Accessed 10 Jan. 2017]. ${ }^{42}$ Ibid., 11; Noha El-Hennawy, "Sisters aspire to equality within Egypt's Muslim Brotherhood," Ikhwan Web (2011) Available at: http://www.ikhwanweb.com/article.php?id=28247 [Accessed July
} 10, 2017]. Following their formation, the Muslim Sisters came under the supervision of the Muslim Brotherhood's male Supreme Guide. In 1948, the decision making structure of the movement was appended by the creation of a committee of twelve elected women, tasked with coordinating local activities (see Talhami, The mobilization of Muslim women in Egypt).

${ }^{43}$ Tadros, The Muslim Brotherhood in Contemporary Egypt: Democracy redefined or confined?, 131.

${ }^{44}$ Erika Biagini, "The Egyptian Muslim Sisterhood between Violence, Activism and Leadership," Mediterranean Politics 22:1 (2017): 35-53; Biagini, “Islamist women's feminist subjectivities in (r)evolution: the Egyptian Muslim Sisterhood in the aftermath of the Arab uprisings." 
six months following the coup. The first recorded protest was staged by Nisaa' Did al-Inqilab (Women Against the Coup) on 26 July in Giza. As should be clear, these protests grew in frequency and intensity following the Rabaa massacre. This upsurge coincided with the emergence of several new women-led movements who publicized their exploits over social media (see Table 1), including Bint al-Thawra (Daughter of the Revolution), Harikat Haqi (My Right Movement), and 7 al-Subh (7 in the Morning). For the first time, Muslim Sisters and other Islamist women organized autonomously, in turn developing their own leadership structures. These movements also helped to pioneer a series of new performances and protest tactics, including night-marches, human chains outside of schools and university campuses during the early morning, and so-called "butterfly protests" (akin to a flash mob). By November 2013, a prominent Muslim Sister proclaimed that, "it has become a duty for the Sisters to lead the protests. This is why they formed many movements. $" 45$

[Table 1 about here]

\section{Data and method}

We begin by using quantitative methods to examine the timing and contexts of this mobilization. Here, our empirical strategy assumes that by systematically observing where and when women protested, we can gain insights into why they were doing so. Our event data is derived from a catalogue of anti-coup protest reports published in the Muslim Brothers' Arabic-language

\footnotetext{
${ }^{45}$ Enas Hamed, "Egypt's 'Muslims Sisterhood' moves from social work to politics," Al-Monitor (2013) Available at: http://www.al-monitor.com/pulse/originals/2013/11/egypt-muslim-sisterhoodsocial-work-politics.html [Accessed 10 Jan. 2020].
} 
newspaper, al-Hurriyya wa-l-Adala.$^{46}$ Between 30 June and 25 December 2013, the newspaper recorded 85 all-women protest events launched by one of the several movements listed above. ${ }^{47}$ We study all-women protests for practical and theoretical reasons. While women also participated in mixed gender protests, their presence was subject to underreporting in anti-coup news media. ${ }^{48}$ When women did participate in mixed gender protests, men typically organized and led the event. Confining attention to all-women protest events thus provides the best available test of where and when female Islamists mobilized autonomously. To study the impact of repression on the organizational capacity of the anti-coup movement, we draw on the WikiThawra database of arrests. WikiThawra is an unusually detailed record of Egyptian state repression, and provides information on the home governorate of 9,201 Islamist males arrested for participation in anti-coup activities between 30 June and 31 December 2013. We also analyze a separate list that was compiled by WikiThawra, which details the home districts of anti-coup protestors killed at Rabaa. ${ }^{49}$

We expand on the quantitative findings by drawing on 13 semi-structured interviews with anti-coup activists ( 7 females and 6 males). ${ }^{50}$ The majority of the interviews were conducted in Cairo and London in the spring of 2014; that is, while the anti-coup movement continued to stage protests across the country. We also used Skype to interview several respondents located in

\footnotetext{
${ }^{46}$ The codebook is summarized in Ketchley, Egypt in a Time of Revolution: Contentious Politics and the Arab Spring, 165-168.

${ }^{47}$ The newspaper ceased publication on 25 December 2013, and so we confine attention to the six months following the coup.

${ }^{48}$ Ketchley, Egypt in a Time of Revolution: Contentious Politics and the Arab Spring, 165.

${ }^{49}$ Neil Ketchley and Michael Biggs, "Who actually died in Egypt's Rabaa massacre," Washington

Post (2015) Available at: https://www.washingtonpost.com/news/monkeycage/wp/2015/08/14/counting-the-dead-of-egypts-tiananmen [Accessed 6 Feb. 2020].

${ }^{50}$ This includes personal correspondence with two Muslim sisters based outside of Egypt conducted in 2017.
} 
Alexandria and the Nile Delta. We use respondents' first name to ensure anonymity. Female members of the anti-coup movement are an extremely difficult to access sub-population, and so ours is inevitably a convenience sample where the sample frame follows a snowball design. Here, our informant testimony is not geared towards making representative claims, but rather to establish whether the patterns identified in our statistical results feature in participants' accounts of how women became involved in street-level mobilization.

\subsection{Dependent variable}

The dependent variable is the occurrence of a protest event launched by a women's anti-coup movement. The unit of analysis is the census district week. We are interested in both time varying and time invariant factors, and so we use a cross-section, time-series design to account for the social contexts of mobilization, as well as any temporally proximate effects of repression and protest. There is very little variation in the scale of protest, and so the dependent variable is binary and modelled using logistic regression. We use random effects to account for the panel structure of our data. Subsequent models reported after the main results test alternative specifications.

\subsection{Independent variables}

[Figure 3 about here]

WikiThawra provides statistics on the number of Islamist males arrested in a governorate. We experimented with various measures for male arrests. In the main analysis we test a cumulative sum of male Islamist arrests in a governorate week per 10,000 males in the population. Alternative measures, such as lagged counts, return substantively similar results. Figure 3 shows the weekly arrest rate by governorate. If women mobilized in areas where the movement's 
mobilizing capacity had been diminished due to a deficit of males, this variable should be positive.

[Figure 4 about here]

WikiThawra also provides information on the home district of 701 protestors killed at Rabaa, and this allows us to account for the role of local grievances in shaping the contexts of women's mobilization. Here, we expect that women affected by Rabaa would be more likely to mobilize, as well as women mobilizing in the home districts of those kills in an attempt to draw attention to the massacre. We expect that any effect of killing to have diminishing marginal returns, and so this variable is transformed to the square root. Note that this variable is set to zero for the weeks before the massacre. To capture the general effect of the Rabaa massacre in patterning the timing of female participation in anti-coup protests, we enter a binary variable for the post-massacre period. The literature on grievances leads us to expect that both of these variables will be positive.

We have competing expectations for local repression in patterning protest by female anticoup movements. One observed expectation is that women will engage in high risk activism to draw attention to recent repression. An alternative reading would have female protestors as more risk averse, and so less likely to protest in areas where the state had recently repressed activism. To test both of these expectations, we enter a lagged binary variable for whether any anti-coup protest was repressed in a district in the previous week. We also expect women to mobilize in districts that have recently hosted male-led anti-coup activism, and so we enter a lagged count of such anti-coup protests in a district transformed to its square root.

The first round of the 2012 elections provides our measure of support for ousted Islamist president Muhammad Mursi (the second round of the election saw extensive tactical voting, and so is less informative). Our observed expectation is that protest will be more likely in districts where Mursi won a higher percentage of the vote. There is good reason to believe that women's 
activism was tied to anti-coup mobilizations on public university campuses, ${ }^{51}$ and so we enter a binary variable for the presence of a public university in a district. We also expect that there will be greater opportunities to participate in protest in more urban areas where political power is concentrated, and so we enter a variable measuring a district's distance from the district housing the governorate building in kilometres, transformed to the square root.

\section{Results}

[Table 1 about here]

Table 1 presents the results with coefficients expressed as odds ratios (the exponent of $\beta$ ). As this is a panel model, an odds ratio should be interpreted as the district-specific probability of a women's protest occurring. The interclass correlation suggests that 28 percent of the variation in the patterning of women's protests is explained by differences between districts.

The cumulative number of Islamist males arrested in a governorate is negatively associated with female mobilization, but this does not approach statistical significance $(\mathrm{p}=.84)$. Surprisingly, the sign for repression in a district is actually positively correlated with protest at $t+1$, but again this does not achieve statistical significance at $\mathrm{p}<.05$. The presence of a public university in a district is a positive and significant predictor of female Islamist mobilization; districts with a university were 2.3 times more likely to see a women's protest compared to districts without a campus. The occurrence of the Rabaa massacre is a substantively important factor in predicting a women's anti-coup protest occurring. Following the massacre, a district was 19.6 times more likely to see a women's protest on a given week, when compared to the preRabaa period. Districts that saw more anti-coup protestors killed at Rabaa were also significantly more likely to host a female Islamist protest. A one standard deviation increase in the rate of

\footnotetext{
${ }^{51}$ Neil Ketchley and Michael Biggs, "The Educational Contexts of Islamist Activism: Elite Students and Religious Institutions in Egypt," Mobilization 22:1 (2017): 57-76.
} 
killing is associated with a 43 percent increase in the odds of a female Islamist protest in that district. Surprisingly, the percentage of the vote won by Muhammad Mursi is negatively associated with female anti-coup protest, but this is not statistically significant. Women's protests were also significantly more likely in districts that had hosted male-led anti-coup protests at $t-1$. Finally, protests were more likely in districts located further away from the governorate centre.

\section{[Table 2 about here]}

As Table 2 shows, these results are robust to rare events logistic regression, as well as logistic regression. Both of these models have standard errors clustered on the census district. Note that without random intercepts, the coefficient for distance to the governorate center remains positive, but becomes statistically insignificant, suggesting that women's protests were more likely to occur at a distance from those districts where the regime's political and coercive apparatus is most concentrated. All other findings are unaffected.

\section{Discussion}

Before discussing our statistical results, we should reflect on a limitation. Our indicators are either ecological or lagged aggregate counts of activity. With this in mind, we cannot definitively attribute the individual characteristics of female protestors to the aggregate characteristics of the contexts in which they are mobilizing. Our research design cannot, for example, definitively establish that the female relatives of protestors killed in Rabaa were more likely to mobilize, although we do find a robust relationship for women's activism in districts where protestors at Rabaa were killed. Despite these limitations, our analysis can nevertheless illuminate the contextual and temporal dynamics that made protest by women-led anti-coup movements in a given district week more or less likely. 
Our quantitative findings suggest that the Rabaa massacre dramatically impacted the opportunities for women's participation in the anti-coup movement: the likelihood of protests by women's anti-coup movements increased significantly and substantively in the post-Rabaa period, and in districts where more anti-coup protestors were killed. Note that this later result is after controlling for recent protest activity by male-led anti-coup groups and district-level electoral support for Mursi, suggesting that those killed at Rabaa is not simply proxying for local Islamist mobilizing capacity. In the spring of 2014, we interviewed Sarah, a 20-year-old foreign languages student at al-Azhar University in Cairo. Like many, she traced her involvement in anti-coup activism to the killing of her fiancé at Rabaa. ${ }^{52}$ Sarah would go on to become a prominent spokesperson for the women's wing of the anti-coup students movements, and would often reference the killing of her fiancé as a motivating factor for continuing her activism. Fadwa, a recent graduate from Damietta, also underlined the importance of Rabaa as a motivating factor in taking to the streets:

\footnotetext{
"The dispersal was the biggest driver for people to protest, many people marched for the first time. The dispersal was the unifying element. People could disagree about the sit-in, its reasons, but no one could disagree about the dispersal and how violent and inhumane it was, so it unified the people. As a consequence, the participation after Rabaa was really strong, people wanted to commemorate the memory of the martyrs, they wanted to stand in solidarity with those who died there. ${ }^{53}$
}

This finding is echoed in an online survey of 300 anti-coup protestors conducted in the spring of 2014, which found that nearly 75 percent of respondents had a close friend or relative

\footnotetext{
${ }^{52}$ Sarah, Interview, 20 Feb. 2014.

${ }^{53}$ Fadwa, personal correspondence, 6 Nov. 2017.
} 
killed while protesting. Unsurprisingly, expressing solidarity with the victims of state repression was one of the most important reasons given for continuing to participate in anti-coup protest. ${ }^{54}$

Interestingly, our principle measure of organizational capacity --- the arrest of more Islamist males in a governorate --- does not significantly predict subsequent protest by women in the same governorate. While our results lend greater support to grievance-based explanations in patterning women's participation in Islamist protests, as compared to solely organizational ones, the Rabaa massacre should also be understood as having organizational implications for the movement and the rise of women-led movements. In interviews, the dispersal and destruction of the movement's protest camp was identified as having had a profound effect on the mobilizing capacity of the Muslim Brotherhood and their allies. Following the Rabaa massacre, the anticoup movement was forced to rapidly decentralize, with new groups and organizations emerging to sustain a protest presence. ${ }^{55}$ As our results above suggest, the formation of women's organizations is, in part, a direct consequence of this dynamic.

Our quantitative results show that women-led anti-coup protests were significantly more likely in districts that had recently seen male-led or mixed gender protests. This is suggestive of coordination between women's movement and the wider anti-coup movement. Interestingly, local instances of repression did not demobilize women's protest activities, suggesting that women did not always shield themselves from the threat of state violence. Protests were also more likely in districts with public universities. This aligns with the case details: many prominent female anti-coup activists were public university students, and university campuses were key sites of mobilization.

\footnotetext{
${ }^{54}$ Neil Ketchley and Michael Biggs, "What is the anti-coup movement protesting for? Washington Post (2014) Available at: https://www.washingtonpost.com/news/monkey-cage/wp/2014/04/04/whatis-the-egyptian-anti-coup-movement-protesting-for/?noredirect=on [Accessed $6 \mathrm{Feb} 2020]$.

${ }^{55}$ Abdullah, interview, 26 Feb. 2014; Muhammad, interview, 26 Feb. 2014.
} 
Note, however, that women engaging in anti-coup activism, especially on mixed sex protests, did not do so with complete autonomy: they often had to overcome opposition from male members of the movement. ${ }^{56}$ Hoda, a member of the al-Azhar branch of Bint Al-Thawra, recalled Muslim Brothers objecting to women's groups leading chants and playing instruments on male-led protests. ${ }^{57}$ Similarly, Maria, a Muslim Sister who was active in the movement's social service provision before the coup, described an ongoing debate about gender roles on the private Facebook group for their university anti-coup branch. Males would often insist that " you shouldn't raise your voices because you are a woman'."58 She continued, "there were examples of girls who fought back ... and took leading roles on the ground and even got arrested several times ... they wanted to participate in resisting, irrespective of the boys' approval." ${ }^{59}$ In justifying their participation, Bint Al-Thawra members pointed to escalating repression and invoked religious precedents dating back to the time of the Prophet Muhammad, including one popular refrain: "there is no difference between men and women in times of jihad" (Hoda, interview, 26 February 2014). This counter-argument crystallized in a video series posted to the Bint al-Thawra Facebook and Youtube accounts called Shaqa'q ar-Rijal (Sisters/Twin Halves of Men), named after an excerpt of one of Prophet Muhammad's sayings. ${ }^{60}$ The series featured a young woman who recounted stories of "revolutionary" women in Islamic history, stressing that

\footnotetext{
${ }^{56}$ Tadros in "Does revolutionary politics reconfigure Islamist women's agency organizationally? and Biagini in "Islamist women's feminist subjectivities in (r)evolution: the Egyptian Muslim Sisterhood in the aftermath of the Arab uprisings" also record instances of Muslim Sisters mobilizing in defiance of the Muslim Brotherhood's organizational structure. A willingness to go against the movement's leadership was also evident during the early days of the 25th January Revolution, when Sisters took to the streets despite instructions to the contrary from the movement's leadership (see Allam, Women and the Egyptian revolution: engagement and activism during the 2011 Arab uprisings, 75-76).

${ }^{57}$ Hoda, interview, 26 February 2014.

${ }^{58}$ Maria, personal correspondence, 3 April 2017.

${ }^{59}$ Ibid.

${ }^{60}$ For more on Shaqa'q ar-Rijal series, see: http://bit.ly/39OaKuv
} 
women had an important equal role to play in resisting repression and injustice. In the same vein, other young women justified their participation based on their own re-interpretation of sharia law. As Sara explained, "Sharia is very wide, there is a lot of room for laxity and understanding... a religious girl can break from the shackles of society [and still] follow sharia." ${ }^{\prime 61}$

Of note, opposition to women's participation in anti-coup activism did not only come from male peers in the movement. Hend, a student at al-Azhar, was barred from participating in some of the larger protests by her parents after the local Muslim Brotherhood branch advised that women should stay at home. ${ }^{62}$ There is also reason to think that towards the end of our analysis period the escalating incidence of sexual violence may have shaped women's opportunities to protest in ways that are possibly not captured by our variables. As one senior Muslim Sister reported, women were asked not to mobilize in certain districts, as the police in those areas had gained a reputation for sexually assaulting female protestors. ${ }^{63}$

\section{Conclusion}

Women's participation in the movement to reinstate ousted Islamist president Muhammad Mursi suggests that harsh repression can feature as a transformative event that temporarily reconstitutes gender roles even within highly patriarchal social movements. Here, women's mobilization often amounted to what Viterna (2013) has called "gender-bending actions": women took to the streets without challenging the conservative gender norms that would otherwise limit their roles, in part because such questioning might hinder their ability to participate in activism. ${ }^{64}$

\footnotetext{
${ }^{61}$ Sara, interview, 15 March 2014.

${ }^{62}$ Hend, interview, December 2014.

${ }^{63}$ Mona interview, 7 August 2014.

${ }^{64}$ Viterna, Women in war the micro-processes of mobilization in El Salvador, 11.
} 
Such activism often came at a personal and social cost. Women in the anti-coup movement faced violent repression and arrest by security forces, as well as sexual violence in prisons, including forced virginity testing. ${ }^{65}$ The stigma of sexual violence featured prominently in our interviews with protestors. Sara, a member of Youth against the Coup, documented violations against women in police stations and prisons; some police stations were so notorious for sexually abusing women that detainees requested to be transferred to prisons where they hoped for more humane treatment. ${ }^{66}$ Women also faced social and personal penalties for their activism, ranging from ostracism to dismissal from university. According to Sara, some women anti-coup activists were perceived by potential male Islamist suitors as having become too autonomous because of their participation in protest: "Don't marry the Azhari girls, they have molotovs for lunch. That's a joke that Islamist men say about al-Azhar --- that they're fierce women ... Bint al-Thawra --- they're paying a heavy price for what they're doing. Their reputations have been ruined for life --- they're unmarriable." ${ }^{67}$ Similarly, Biagini (2019) finds that some women activists were stigmatized for their "unfeminine" and "immodest" behaviour, while others were even expelled from the movement. In such cases, women highlighted "the abuses of the authoritarian state and those of the MB [Muslim Brotherhood], perceiving both as instruments of women's oppression." 68

The subsequent demobilization of women's anti-coup groups --- alongside other male-led anti-coup movements --- by the winter of 2015 is suggestive of a familiar pattern, whereby temporarily empowered women step back from frontline protest activities. We see something

${ }^{65}$ Middle East Monitor "Female prisoners tortured and sexually abused in Egypt's jails," (2014) Available at: https://www.middleeastmonitor.com/20140322-female-prisoners-tortured-and-sexuallyabused-in-egypts-jails/ [Accessed 6 Feb. 2020].

${ }^{66}$ Sara, interview, 15 March 2014.

${ }^{67}$ Ibid..

${ }^{68}$ Biagini, “Islamist women's feminist subjectivities in (r)evolution: the Egyptian Muslim Sisterhood in the aftermath of the Arab uprisings," 14. 
similar in Algeria and El Salvador, where most women shifted back to their gendered responsibilities as homemakers and mothers after time spent participating in activism. ${ }^{69}$ This suggests that while harsh repression can figure as a transformative event that can alter gender dynamics in highly patriarchal movements, the effect is temporary. In Egypt, as in elsewhere, the extent and duration of women's participation was ultimately tried to the fate and trajectory of the broader anti-coup mobilization. Further research is required to establish how women's experiences of participating in frontline activism has impacted the broader position of women within both the Muslim Brotherhood and other cognate Islamist movements in Egypt.

\footnotetext{
${ }^{69}$ Viterna, Women in war the micro-processes of mobilization in El Salvador; Maloba, African women in revolution.
} 


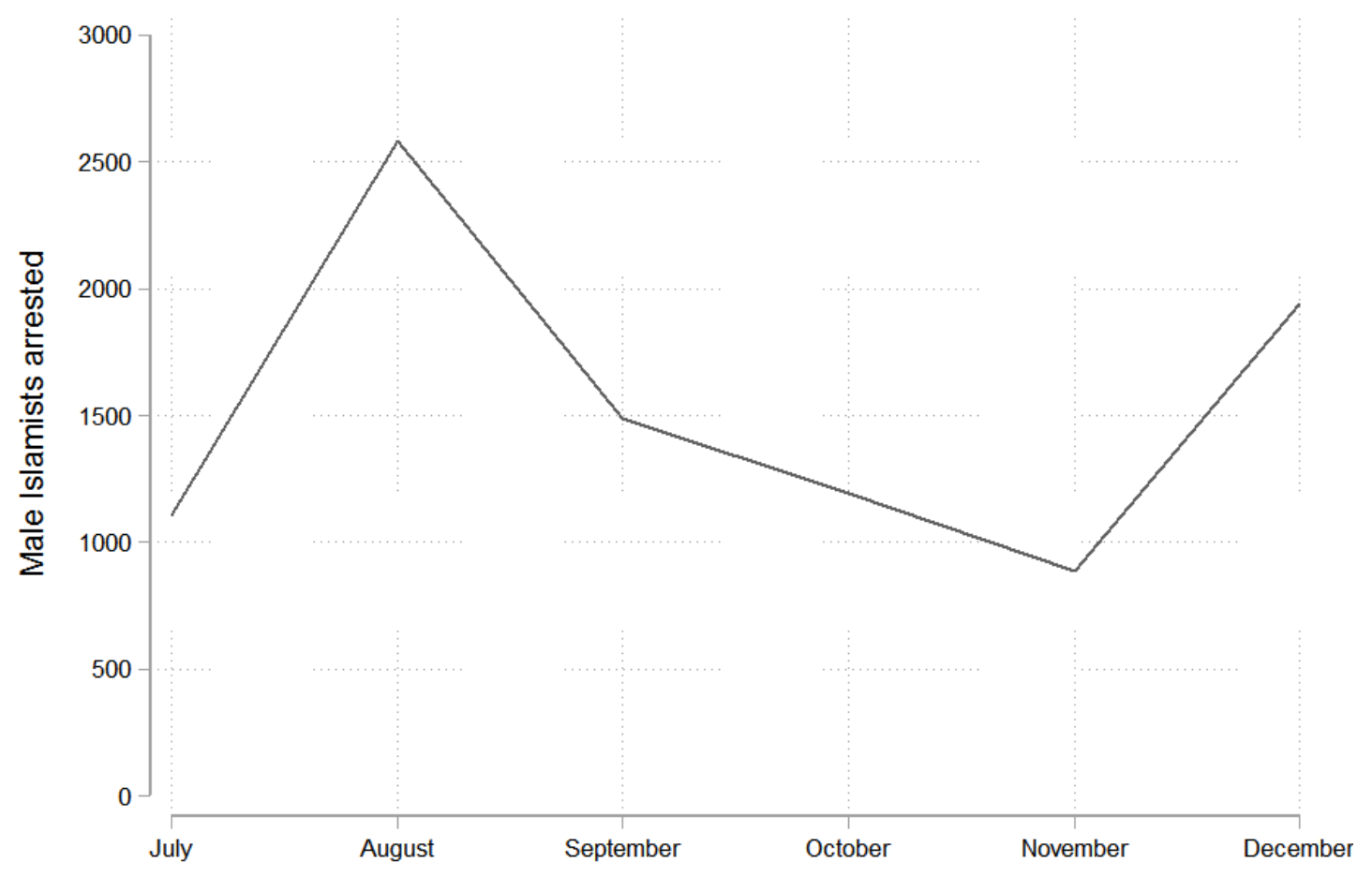

Figure 1. Arrest rate for Islamist males, Jul.-Dec. 2013. Source: WikiThawra 


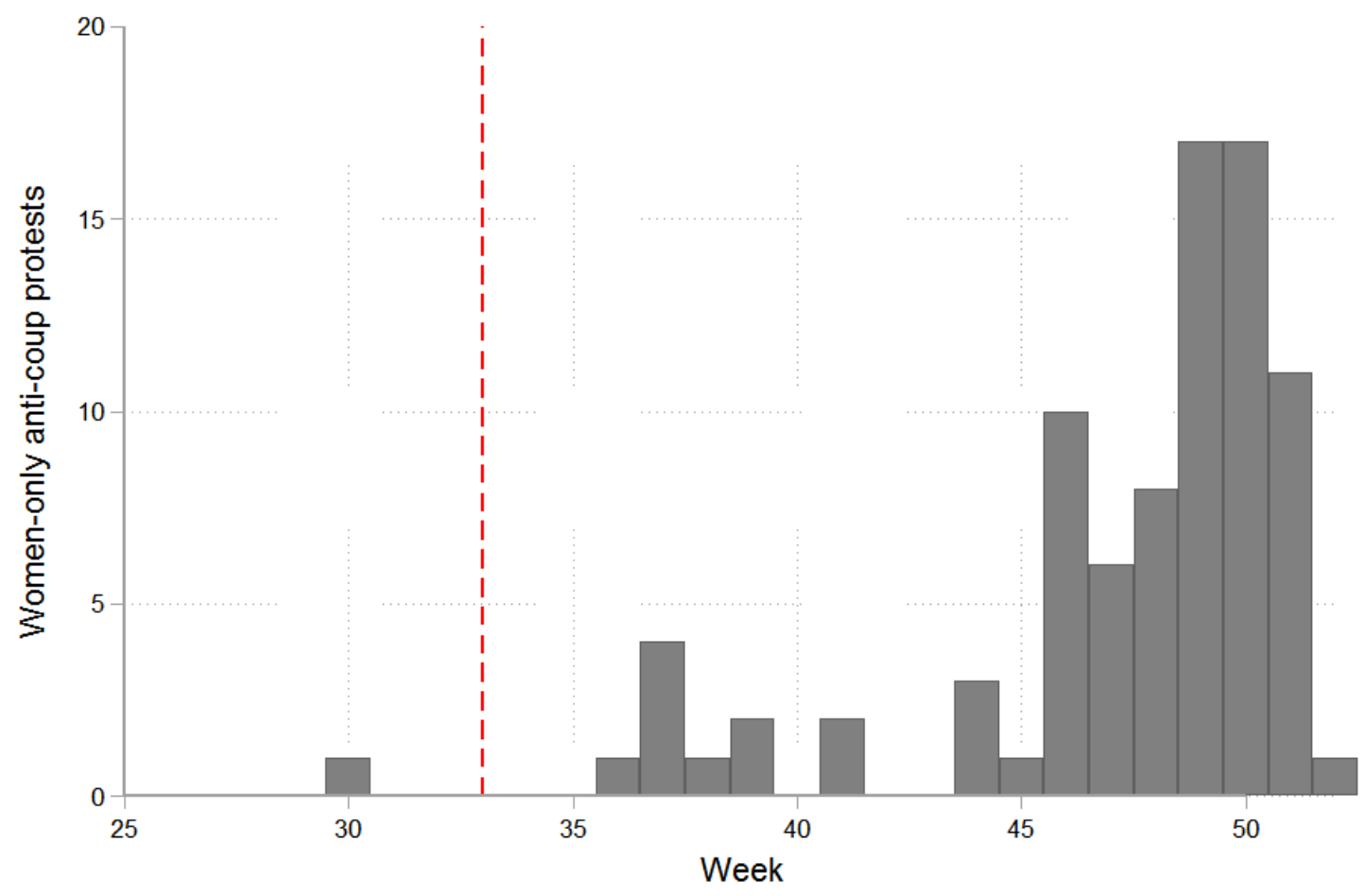

Figure 2. Women-only anti-coup protests, Jul.-Dec. 2013. Notes: the dashed y-line marks the week of the Rabaa massacre. 


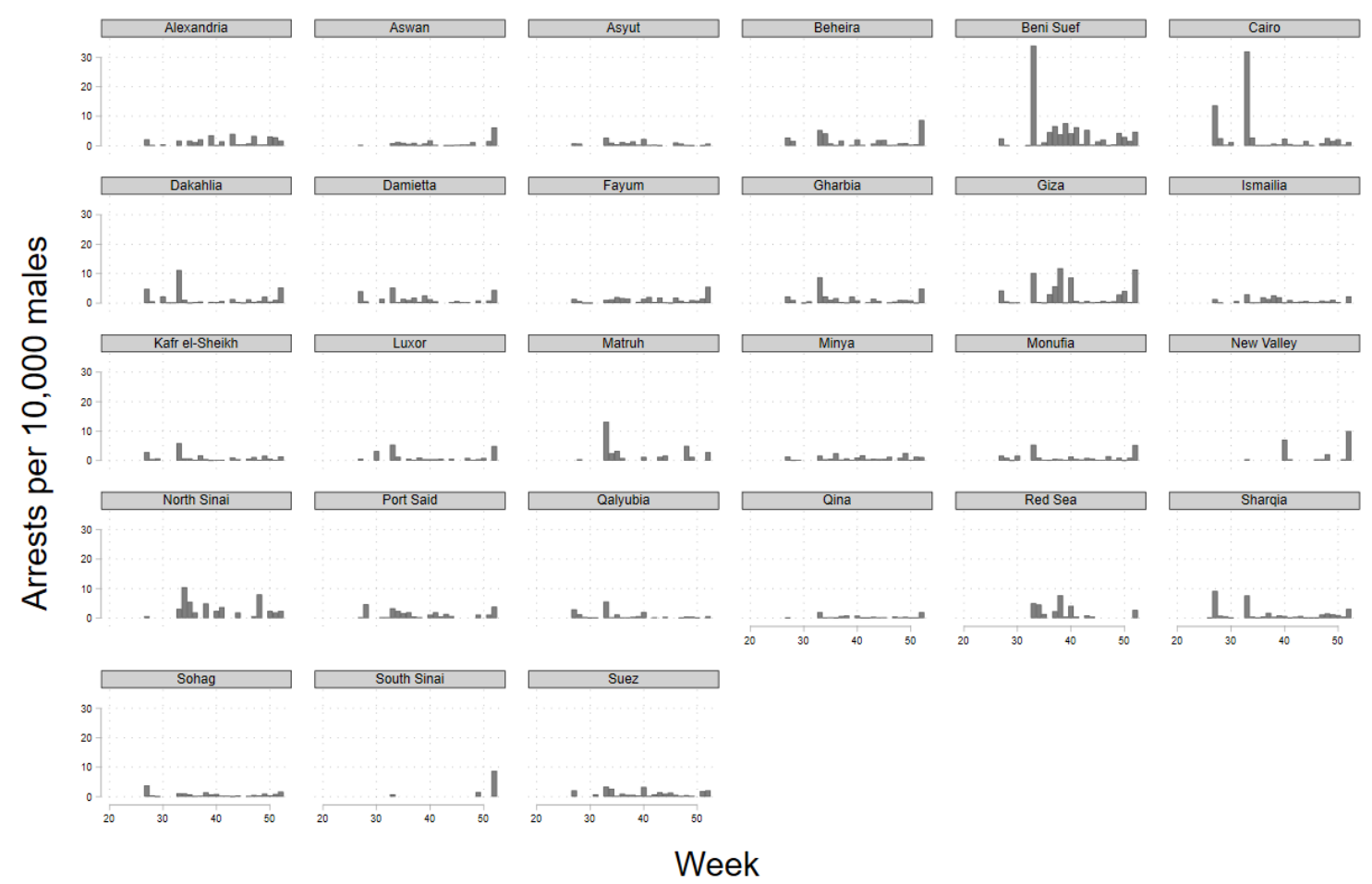

Figure 3. Arrest rate of Islamists per 10,000 males by governorate week. 
Table 1. Women's anti-coup movements

\begin{tabular}{|c|c|c|c|}
\hline Movement & Areas active & Activities & Website \\
\hline $\begin{array}{l}\text { Nisaa' Did al- } \\
\text { Inqilab }\end{array}$ & Nationwide & $\begin{array}{l}\text { Coordinating women-led } \\
\text { marches and demonstrations; } \\
\text { documenting human rights } \\
\text { violations; providing statistics } \\
\text { about women detainees and } \\
\text { incidents of sexual violence. }\end{array}$ & $\begin{array}{l}\underline{\text { https://www. }} \\
\text { facebook.co } \\
\text { m/WomenAn } \\
\underline{\text { tiCoup/ }}\end{array}$ \\
\hline Bint al-Thawra & $\begin{array}{l}\text { Al-Azhar } \\
\text { University } \\
\text { campuses }\end{array}$ & $\begin{array}{l}\text { Coordinating sit-ins, marches, } \\
\text { and exam strikes on university } \\
\text { campuses; campaigns to raise } \\
\text { awareness about women } \\
\text { detainees and expulsions; } \\
\text { providing updates about prison } \\
\text { sentences and releases. }\end{array}$ & $\begin{array}{l}\underline{\text { https://www. }} \\
\underline{\text { facebook.co }} \\
\underline{\text { m/bent.elthw }} \\
\underline{\text { ra/ }}\end{array}$ \\
\hline Harikat Haqi & $\begin{array}{l}\text { Schools and } \\
\text { universities in } \\
\text { Asyut }\end{array}$ & $\begin{array}{l}\text { Staging marches, student sit-ins } \\
\text { inside schools, and night } \\
\text { protests, sometimes alongside } \\
\text { male-led "Students Against the } \\
\text { Coup." Online awareness } \\
\text { campaigns about human rights } \\
\text { violations and the arrest of } \\
\text { female students. }\end{array}$ & $\begin{array}{l}\frac{\text { https://www. }}{\text { facebook.co }} \\
\underline{\mathrm{m} / 7 \mathrm{a} 9 \text { y.assui }} \\
\underline{\mathrm{t}}\end{array}$ \\
\hline 7 al-Subh & $\begin{array}{l}\text { Alexandria, } \\
\text { Cairo, } \\
\text { Damietta, and } \\
\text { the Nile Delta }\end{array}$ & $\begin{array}{l}\text { Staging early morning sit-ins and } \\
\text { human chains outside of schools } \\
\text { and besides main roads during } \\
\text { the morning rush hour. Involved } \\
\text { in a campaign to raise awareness } \\
\text { about the arrest of } 21 \text { of their } \\
\text { members in October } 2013 \text {. The } \\
\text { case gained international media } \\
\text { attention leading to their } \\
\text { eventual release. }\end{array}$ & $\frac{\text { https://twitter }}{\frac{. \mathrm{com} / 7 \text { elsob }}{\underline{7}}}$ \\
\hline
\end{tabular}


Table 2. Predicting the probability of a women's anti-coup protest

\begin{tabular}{|c|c|}
\hline & $\begin{array}{c}(1) \\
\text { Random } \\
\text { effects } \\
\text { logistic } \\
\text { regression }\end{array}$ \\
\hline $\begin{array}{l}\text { Cumulative Islamist males arrested in governorate per } \\
10,000 \text { males }\end{array}$ & $\begin{array}{c}0.998 \\
(-0.21)\end{array}$ \\
\hline Male-led anti-coup protests in district (sqrt, $t-1$ ) & 2.694 \\
\hline & $(4.90)^{* * *}$ \\
\hline Anti-coup protest repressed in district $(t-1)$ & 1.522 \\
\hline & $(1.22)$ \\
\hline Public university in district & 2.298 \\
\hline & $(2.04)^{*}$ \\
\hline Post-Rabaa massacre & 19.656 \\
\hline & $(2.86)^{* *}$ \\
\hline Killed at Rabaa from district (sqrt) & 1.352 \\
\hline & $(1.99)^{*}$ \\
\hline District's distance from governorate centre (sqrt, km) & 1.053 \\
\hline & $(1.82)$ \\
\hline Voted for Mursi in district (\%) & 0.977 \\
\hline & $(-1.32)$ \\
\hline Random intercept: district (standard deviation) & $\begin{array}{c}1.120 \\
(4.41)^{* * *}\end{array}$ \\
\hline
\end{tabular}

$\begin{array}{ll}\text { District weeks } & 8,502\end{array}$

Z-scores in parentheses

p-value (two-tailed), $* * * \mathrm{p}<.001, * * \mathrm{p}<.01, * \mathrm{p}<.05$ 
Table 3. Alternative specifications

(2)

(3)

Rare

Logistic

events

\begin{tabular}{|l|c|c|}
\hline $\begin{array}{l}\text { Cumulative Islamist males arrested in governorate per } \\
\text { 10,000 males }\end{array}$ & $\begin{array}{c}0.992 \\
(-1.06)\end{array}$ & $\begin{array}{c}0.992 \\
(-1.15)\end{array}$ \\
\hline Male-led anti-coup protests in district (sqrt, $t$ - 1$)$ & 3.077 & 3.090 \\
\hline & $(4.87)^{* * *}$ & $(4.88)^{* * *}$ \\
\hline Anti-coup protest repressed in district $(t-1)$ & 1.613 & 1.600 \\
\hline & $(1.63)$ & $(1.60)$ \\
\hline Public university in district & 1.915 & 1.900 \\
\hline & $(2.00)^{*}$ & $(1.97)^{*}$ \\
\hline Post-Rabaa massacre & 13.942 & 23.215 \\
\hline & $(2.43)^{*}$ & $(2.90)^{* *}$ \\
\hline Killed at Rabaa from district (sqrt) & 1.319 & 1.322 \\
\hline & $(2.09)^{*}$ & $(2.11)^{*}$ \\
\hline Voted for Mursi in district $(\%)$ & 1.054 & 1.053 \\
\hline District's distance from governorate centre (sqrt, km) & $(2.50)^{*}$ & $(2.41)^{*}$ \\
\hline & 0.980 & 0.979 \\
\hline & $(-1.43)$ & 8,502 \\
\hline
\end{tabular}

Z-scores in parentheses; standard errors clustered on census district p-value (two-tailed), $* * * \mathrm{p}<.001, * * \mathrm{p}<.01,{ }^{*} \mathrm{p}<.05$ 